\title{
FEASIBILITY OF SUBMATERY DOCUMENTARY FILM OF DIVERSITY CONCEPTS, TYPES, ECOSYSTEMS BASED ON NEPENTHES
}

\author{
Alexander Sardi, Syamswisna, Titin* \\ Program Studi Pendidikan Biologi, Fakultas Matematika dan Ilmu Pengetahuan Alam \\ Universitas Tanjungpura \\ Jalan Prof Dr. Hadari Nawawi, Pontianak, Indonesia \\ *titin@ fkip.untan.ac.id
}

Doi: 10.31943/mangiferaedu.v5i2.93

Received: May 6, 2020 Accepted: December 17, $2020 \quad$ Published: January 31, 2021

Citation: Sardi, A., Syamswisna, \& Titin. (2021). Feasibility of Submatery Documentary

Film of Diversity Concepts, Types, Ecosystems Based on Nepenthes. Jurnal Mangifera Edu, 5(2), 78-92.

\begin{abstract}
This research aimed to know the Nepenthes plant species in the Nanga Nyabau forest, Kapuas Hulu Regency, and determine the feasibility of documentary film media as a learning media in the Submission of the Concept of Diversity in Genes, Types, and Ecosystems. This research was conducted through two stages. First, the Nepenthes inventory in the Nanga Nyabau Indigenous Forest, Kapuas Hulu District, then continued with the making and feasibility test of documentary films as learning media. The form of this research was descriptive. Sampling used a purposive sampling technique with the explored method. The documentary media was tested for feasibility by five validators. The validators are two lecturers of Biology Education Study Program FKIP Universitas Tanjugpura, one Biology teacher in class X of SMA Negeri 1 Putussibau, one Biology teacher in class X SMA Negeri 2 Putussibau, and one teacher of Biology in class X of SMAS Karya Budi Putussibau. Based on the results, there were five types of Nepenthes plants, namely Nepenthes bicalcarata, Nepenthes mirabilis var. echinostoma, Nepenthes rafflesiana Jack., Nepenthes reinwardtiana, and Nepenthes xneglecta. The CVI value of documentary film media was one and categorized valid to be used as a learning media
\end{abstract}

Keywords: Documentary Film Media, Feasibility, Learning Media, Nephentes

\begin{abstract}
ABSTRAK
Penelitian ini bertujuan untuk mengetahui jenis tumbuhan Nepenthes di hutan Nanga Nyabau Kabupaten Kapuas Hulu dan mengetahui kelayakan media film dokumenter sebagai media pembelajaran dalam Penyampaian Konsep Keanekaragaman Gen, Jenis, dan Ekosistem. Penelitian ini dilakukan melalui dua tahap. Tahap pertama inventarisasi Nepenthes di Hutan Adat Nanga Nyabau Kabupaten Kapuas Hulu dan tahap kedua pembuatan dan uji kelayakan film dokumenter sebagai media pembelajaran. Bentuk penelitian ini adalah deskriptif. Pengambilan sampel menggunakan teknik purposive sampling dengan metode eksplorasi. Media dokumenter diuji kelayakannya oleh lima validator. Validatornya adalah dua orang dosen Prodi Pendidikan Biologi FKIP Untan, satu guru Biologi kelas X SMA Negeri 1 Putussibau, satu guru Biologi kelas X SMA Negeri 2 Putussibau, dan satu guru Biologi kelas X SMAS Karya Budi Putussibau. Berdasarkan
\end{abstract}


hasil penelitian didapatkan 5 jenis tumbuhan Nepenthes yaitu Nepenthes bicalcarata, Nepenthes mirabilis var. echinostoma, Nepenthes rafflesiana Jack., Nepenthes reinwardtiana, dan Nepenthes xneglecta. Nilai CVI media film dokumenter adalah 1 dan kategori valid untuk digunakan sebagai media pembelajaran.

Kata Kunci: Kelayakan, Media Film Dokumenter, Media Pembelajaran, Nephentes

\section{PENDAHULUAN}

Pembelajaran merupakan usaha membimbing dan memotivasi peserta didik untuk mengembangkan potensi untuk mencapai kualitas diri yang lebih baik (Kurniawan, 2018). Biologi sebagai salah satu rumpun pelajaran sains mengutamakan fakta-fakta dalam pembelajarannya sehingga menjadi wahana bagi peserta didik untuk mempelajari diri sendiri, alam sekitar, dan prospek pengembangan lebih lanjut dalam penerapan kehidupan sehari-hari (Rahman, 2017). Proses pembelajaran biologi menekankan pada pemberian pengalaman langsung untuk mengembangkan kompetensi agar peserta didik dapat menjelajahi dan memahami alam sekitar secara ilmiah, contohnya pada materi keanekaragaman hayati yang membahas tentang tingkat keanekaragaman tumbuhan dan hewan yang ada di Indonesia (Afifah \& Marlina, 2016).

Observasi awal tentang hasil belajar peserta didik kelas X di SMA Negeri 1 Putussibau pada submateri keanekaragaman gen, jenis, dan ekosistem mencapai 74,42. Artinya rata-rata nilai tersebut belum mencapai KKM yang ditentukan, yaitu 75 . Ketuntasan pencapaian KKM hanya 29.9\% dari total 107 peserta didik. Hal ini menunjukkan bahwa masih tingginya angka ketidaktuntasan peserta didik pada materi keanekaragaman hayati dikarenakan peserta didik mengalami kesulitan untuk memahami konsep. Kesulitan tersebut salah satunya diakibatkan penggunaan media pembelajaran yang kurang maksimal, terutama ketika menyajikan hasil observasi berbagai tingkat keanekaragaman hayati khususnya pada keakeragaman gen, jenis, ekosistem. Hal ini didukung oleh hasil wawancara dengan dua orang peserta didik kelas X-IPA-1 yang menyatakan bahwa pembelajaran materi keanekaragaman hayati selama ini berfokus pada buku teks dan penyampaian materi dengan metode ceramah tanpa disertai media pembelajaran untuk menunjang penyampaian materi. Sementara peserta didik dituntut untuk mampu memahami konsep daripada hanya sekadar menghafal (Maxtuti, 2013). Tuntutan kuriulum terhadap peserta didik pada materi keanekaragaman hayati sebagaimana tertuang dalam Kompetensi Dasar 4.2, yaitu peserta didik dapat 
menyajikan hasil observasi berbagai tingkat keanekaragaman hayati di Indonesia dan usulan pelestariannya.

Upaya untuk membantu peserta didik dalam memahami materi keanekaragaman hayati dan menunjang kegiatan observasi, yaitu dengan pemberian media pembelajaran yang sesuai. Media yang diberikan harus dapat membantu peserta didik dalam memahami konsep yang disampaikan oleh guru, mendukung terbentuknya proses belajar yang menyenangkan, dan membantu peserta didik dalam kegiatan observasi keanekaragaman hayati di sekitarnya sehingga dapat menarik perhatian peserta didik untuk belajar dan meningkatkan pemahamannya (Sudjana, 2009). Hal ini dikarenakan media pembelajaran merupakan alat atau bentuk stimulus yang berfungsi untuk menyampaikan pesan pembelajaran (Rusman, 2017).

Menurut Rikarno (2015), salah satu media penyampaian informasi atau media pembelajaran adalah melalui film dokumenter. Film dokumenter merupakan film yang dibuat berdasarkan fakta bukan fiksi dan bukan pula memfiksikan fakta (Munadi, 2013). Film dokumenter dibuat dengan cara menggabungkan tulisan, gambar, dan suara yang mudah dipahami dan dicerna masyarakat sehingga dapat menarik perhatian dan fokus dalam penyampaian pesan (Utami, 2010). Film dokumenter sebagai media pembelajaran memiliki pengaruh terhadap hasil belajar peserta didik pada materi ruang lingkup biologi (Dara \& Panjaitan, 2016) dan juga meningkatkan prestasi belejar peserta didik pada ranah kognitif dan afektif (Panjaitan et al., 2019). Sifat dari film dokumenter harus berdasarkan fakta bukan fiksi sehingga film dokumenter menjadi alat komunikasi yang dapat membantu proses pembelajaran efektif (Wardhani \& Sudjudi, 2014). Kelebihan dari film dokumenter menurut Sadiman et al., (2000), dapat mengatasi keterbatasan jarak dan waktu, mampu menggambarkan peristiwa-peristiwa masa lalu secara realistis dalam waktu yang singkat, dapat diulangi untuk menambah kejelasan, pesan yang disampaikan cepat dan mudah diterima, mengembangkan pikiran dan pendapat para peserta didik, mengembangkan imajinasi peserta didik, memperjelas hal-hal yang abstrak, dan memberikan gambaran yang lebih realistis terhadap objek yang diamati.

Film dokumenter dalam penelitian ini menggunakan hasil inventarisasi Nepenthes sebagai dasar pembuatan. Nepenthes adalah tumbuhan yang memiliki kantong pada ujung daunnya. Kantong ini memiliki berbagai bentuk, ukuran, dan warna yang beranekaragam sehingga menarik untuk dilihat (Handayani, 2017). Dasar klasifikasi untuk membedakan setiap jenis Nepenthes yaitu dengan melihat karakter morfologi Nepenthes yang meliputi bentuk kantong dan warna kantong. Terdapat lima tipe habitat utama spesies Nepenthes yaitu 
Jurnal Mangifera Edu, Volume 5, Nomor 1, Juli 2020, 26-37

hutan hujan tropis dataran rendah, hutan kerangas, hutan gambut, hutan pegunungan, dan bukit kapur (Clarke \& Moran, 2016). Morfologi dan habitat Nepenthes dipelajari untuk menunjang pemenuhan Kompetensi Dasar 4.2 sehingga film dokumenter yang dibuat harus dapat mendukung kegiatan observasi peserta didik.

Film dokumenter sebagai media pembelajaran diharapkan dapat menumbuhkan minat dan motivasi siswa dalam mengeksplorasi dan mempelajari materi keanekaragaman hayati sehingga peserta didik dapat lebih mudah memahami konsep keanekaragaman dan pentingnya pelestarian plasma nutfah. Berdasarkan latar belakang tersebut, penelitian ini bertujuan untuk mendeskripsikan kelayakan film dokumenter inventarisasi Nepenthes di Hutan Adat Nanga Nyabau Kabupaten Kapuas Hulu pada submateri keaneragaman gen, jenis, ekosistem.

\section{METODOLOGI PENELITIAN}

Bentuk penelitian ini adalah penelitian kuantitatif, yaitu penelitian yang berlandaskan pada filsafat positivisme, digunakan untuk meneliti pada populasi atau sampel tertentu (Sugiyono, 2010). Teknik pengambilan sampel pada umumnya dilakukan secara random yang dalam penelitian ini adalah ahli materi dan ahli media. Pengumpulan data menggunakan instrumen penelitian berupa lembar validasi film dokumenter, analisis data bersifat kuantitatif/statistik. Penelitian kuantitatif yang dimaksudkan dalam penelitian ini adalah pembuatan dan uji kelayakan film dokumenter pada materi keanekaragaman gen, jenis, dan ekosistem berdasarkan hasil inventarisasi di Hutan Adat Nanga Nyabau. Penelitian kuantitatif ini dilaksanakan melalui 6 tahap, yaitu pembuatan synopsis, storyboard, script atau naskah cerita, pembuatan skenario, validasi, analisis data mengikuti langkah pembuatan yang di modifikasi dari (Sadiman et al., 2000).

Tahap pertama adalah Sinopsis yang merupakan ringkasan atau garis besar yang menggambarkan tentang urutan cerita dalam naskah (Cikka, 2019). Sinopsis media film dokumenter pada inventarisasi Nepenthes adalah dengan membuat urutan cerita dalam film dimulai dari Kompetensi Dasar dan tujuan pembelajaran pada materi keanekaragaman hayati, menampilkan judul dari submateri keanekaragaman gen, jenis, ekosistem, dilanjutkan dengan menampilkan penjelasan keanekaragaman tingkat gen dan penyebab terjadinya keanekaragaman tingkat gen disertai contoh dari hasil inventarisasi Nepenthes, dilanjutkan penjelasan mengenai keanekaragaman tingkat jenis dan penyebab terjadinya keanekaragaman tingkat jenis disertai dengan contoh dari hasil inventarisasi Nepenthes, kemudian dilanjutkan dengan penjelasan mengenai keanekaragaman tingkat ekosistem dan 
penyebab terjadinya keanekaragaman ekosistem disertai dengan contoh dari ekosistem yang ada di lokasi inventarisasi Nepenthes, dan penutup berupa wawancara dengan masyarakat.

Tahap kedua yang dilakukan adalah pembuatan Storyboard yang merupakan alat perencanaan berupa sketsa atau deskripsi dari setiap scene yang secara jelas menggambarkan objek multimedia serta perilakunya (Khulsum et al., 2018). Storyboard ini di dalamnya dibuat frame-frame berisi perilaku yang akan dilakukan dalam film dokumenter, lalu merencanakan instrumen musik yang akan digunakan dalam setiap frame. Selain itu juga dilakukan perencanaan durasi setiap frame nya.

Tahap ketiga yaitu script atau naskah yang merupakan karangan yang bertulis tangan atau diketik (Chulsum \& Novia, 2016). Oleh sebab itu dalam film dokumenter ini terdapat naskah atau tulisan yang menyampaikan informasi mengenai inventarisasi Nepenthes yang terdiri dari 3 bagian yaitu bagian pendahuluan, bagian isi, dan bagian penutup.

Tahap keempat yaitu pembuatan skenario yang merupakan sebuah naskah cerita yang menguraikan urutan suatu adegan, tempat, keadaan dan dialog, yang disusun dalam konteks struktur dramatik sebagai acuan dalam pembuatan suatu film (Pamuji, 2020). Oleh karena itu dalam tahap pembuatan skenario ini dilakukan pengisian suara (dubbing), pemotongan, dan penyisipan gambar atau video yang diperlukan dalam film dokumenter baik dari hasil dokumentasi inventarisasi maupun dari sumber pelengkap seperti video dari platform youtube.

Tahap kelima ialah validasi film divalidasi untuk melihat kelayakannya sebagai media pembelajaran. Validasi merupakan derajat ketetapan antara data yang terjadi ada objek penelitian dengan data yang dapat dilaporkan oleh peneliti. Artinya data yang valid adalah data yang sesungguhnya terjadi pada objek penelitian (Sugiyono, 2010). Validasi produk dapat di lakukan dengan cara menghadirkan ahli materi dan ahli media yang sudah berpengalaman untuk menilai produk baru yang dirancang yaitu media film dokumenter. Validasi dilakukan oleh lima orang validator yang terdiri dari dua orang dosen dan tiga orang guru mata pelajaran Biologi. Adapun dasar dari pemilihan validator adalah purposive sampling dengan pertimbangan kemampuan memvalidasi. Lembar validasi media film dokumenter menggunakan empat aspek dan 14 kriteria modifikasi dari lembar validasi yang dirancang oleh Pratiwi et al., (2015) dan Smaldino et al., (2014). Skala yang digunakan untuk lembar validasi ialah skala likert untuk mengukur sikap, pendapat, dan persepsi seseorang atau sekelompok orang tentang fenomena sosial dengan nilai 4 Baik Sekali (BS), nilai 3 Baik (B), nilai 2 Kurang Baik (KB), dan nilai 1 Tidak Baik (TB) (Joshi et al., 2015). 
Tahap keenam yang merupakan analisis validasi film dokumenter menggunakan metode analisis Content Validity Ratio (CVR). Menurut Lawshe, (1975), CVR merupakan sebuah pendekatan validitas isi untuk mengetahui kesesuaian item dengan domain yang diukur berdasarkan judgement para ahli atau validator. Adapun rumus analisis CVR terdapat pada rumus 1 .

$$
C V R=\frac{N e-\frac{N}{2}}{\frac{N}{2}}
$$

Keterangan:

$$
\begin{aligned}
\mathrm{CVR}= & \text { Content Validity Ratio } \text { (Rasio Validitas Konten) } \\
\mathrm{Ne} & =\text { Jumlah panelis / validator } \\
& \text { yang menyetujui kevalidan film dokumenter (dianggap setuju jika nilai setiap } \\
& \text { kriteria mencapai } 3,00-4,00, \text { jika }<3,00 \text { maka dianggap tidak menyetujui } \\
& \text { kevalidan film dokumenter) } \\
= & \text { Jumlah panelis/validator seluruhnya }
\end{aligned}
$$

Ketentuan tentang indeks CVR sebagai berikut:

a. Saat jumlah responden yang menyatakan setuju atau sangat setuju kurang dari $1 / 2$ total responden (5) maka nilai CVR = -

b. Saat jumlah responden yang menyatakan setuju atau sangat setuju $1 / 2$ setengah dari total responden (5) maka nilai $\mathrm{CVR}=0$

c. Saat seluruh responden (5) menyatakan setuju atau sangat setuju maka nilai CVR = 1 . Karena jumlah responden yang digunakan dalam penelitian ini ada (5) orang, maka nilai kritis CVR $=1$.

d. Saat jumlah responden yang menyatakan setuju atau sangat setuju lebih dari $1 / 2$ total responden maka nilai CVR =0-1 (Lawshe, 1975).

Setelah dilakukan perhitungan nilai CVR setiap kriteria kemudian dihitung nilai CVI (Content Validity Index) atau nilai rata-rata CVR secara keseluruhan untuk menggambarkan bahwa secara keseluruhan butir-butir instrumen mempunyai validasi isi yang lebih baik. Adapun rumus CVI menurut Lawshe, (1975) terdapat pada rumus 2.

$$
C V I=\frac{C V R}{\sum n}
$$

Keterangan:

$\mathrm{n} \quad=$ jumlah item seluruh aspek

CVI = rata-rata CVR

Apabila nilai CVI berada pada kisaran 0-1, maka instrumen dapat dikategorikan baik. Jika setengah dari jumlah validator mengatakan valid, maka film dokumenter dapat 
Jurnal Mangifera Edu, Volume 5, Nomor 1, Juli 2020, 26-37

dikatakan valid dengan baik. Namun, jika kurang dari setengah dari validator mengatakan tidak valid, maka media dikatakan tidak valid. Jika perhitungan akhir skor CVR dan CVI yang memenuhi nilai batas minimum yaitu 0,99 atau 1 , maka media dinyatakan valid dan layak digunakan sebagai media pembelajaran konsep keanekaragaman gen, jenis, dan ekosistem. Apabila nilai CVI berada pada selang 0-1, maka perbaikan film dokumenter dapat dilakukan pada kriteria tertentu yang tidak valid.

\section{HASIL DAN PEMBAHASAN}

Film dokumenter Nephentes dibuat melalui pengambilan gambar kegiatan inventarisasi Nepenthes yang dilakukan di Hutan Adat Nanga Nyabau. Pengambilan gambar untuk pembuatan film dokumenter menggunakan kamera Canon 750D tipe DSLR dan pengeditan video menggunakan aplikasi Wondershare Filmora. Dubbing suara dilakukan perekaman langsung pada aplikasi Wondershare Filmora maupun menggunakan alat perekam suara lainnya. Film dokumenter memuat beberapa bagian yang ditampilkan, menyesuaikan berdasarkan urutan submateri keanekaragaman gen, jenis, dan ekosistem dengan dimulai pada bagian pembukaan, dilanjutkan bagian keanekaragaman gen, bagian keanekaragamana jenis, bagian keanekaragaman ekosistem, dan bagian penutup. Tampilan film dokumenter yang dibuat dapat dilihat pada Gambar 1.
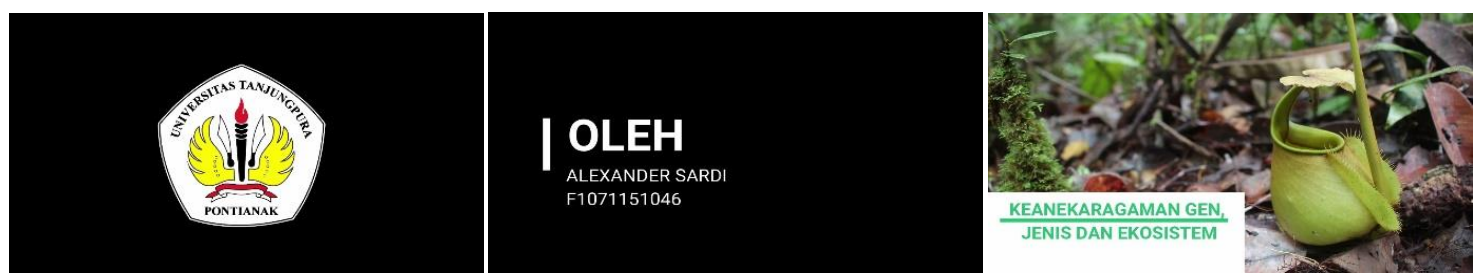

(a)
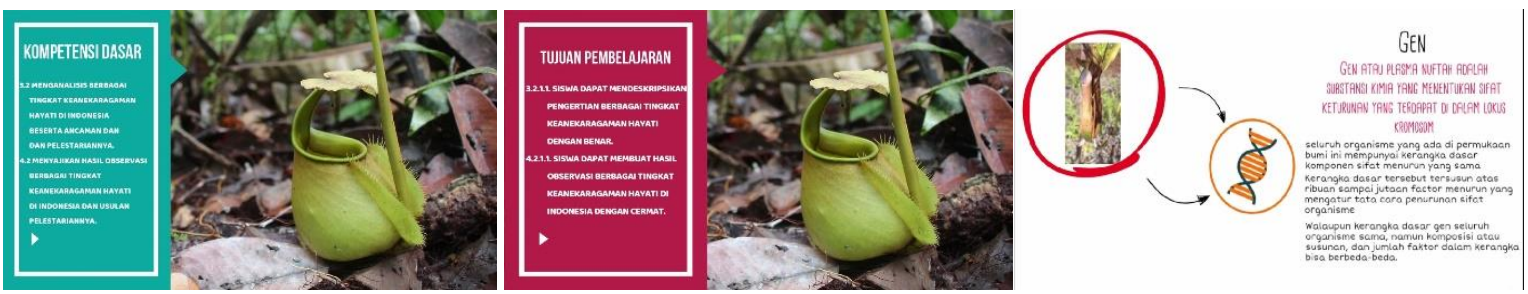

(b)
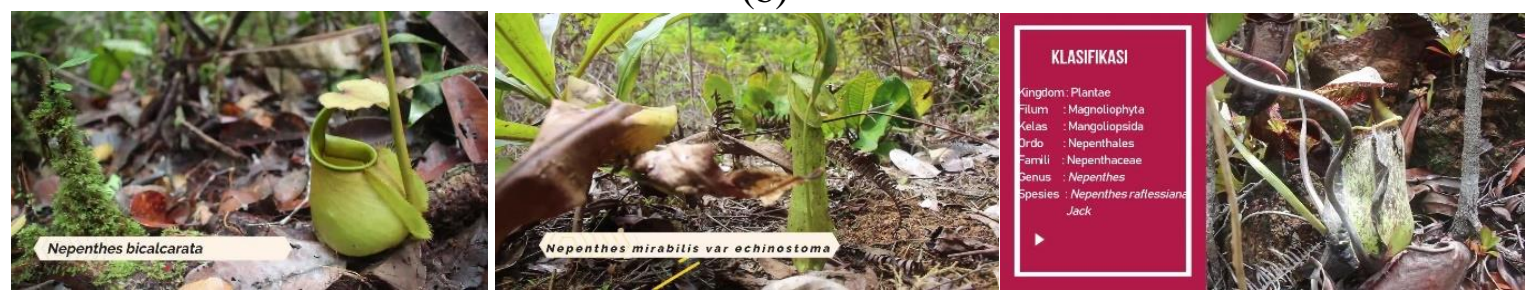

(c) 

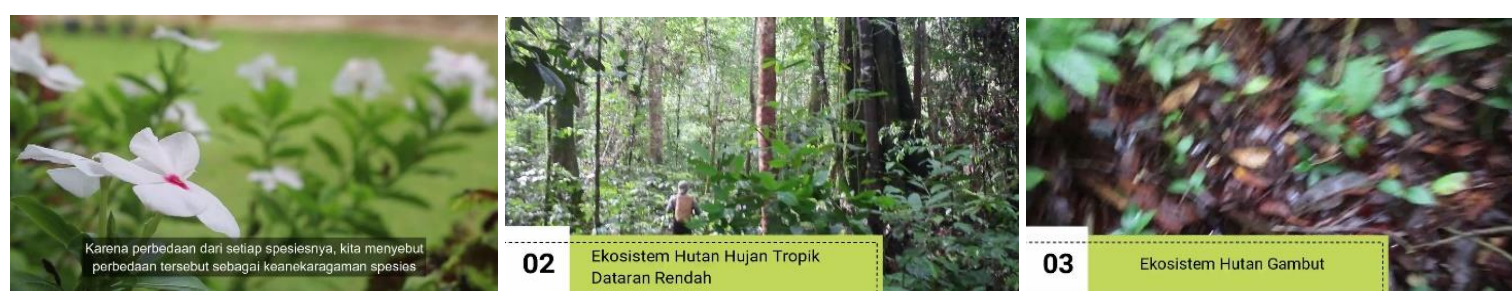

(d)
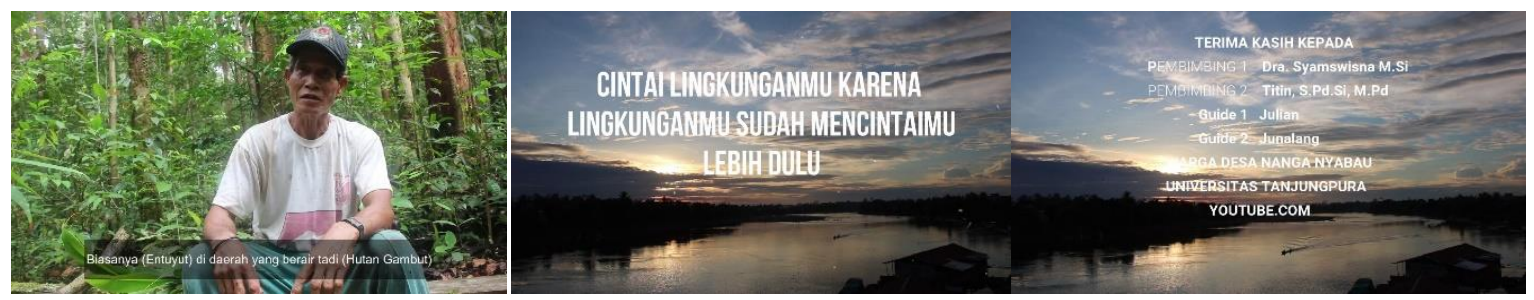

(e)

Gambar 1. Tampilan Film Dokumenter : (a) Bagian Pembukaan, (b) Bagian Keanekaragaman Gen, (c) Bagian Keanekaragaman Spesies, (d) Bagian Keanekaragaman Ekosistem, (e) Bagian Penutup

Setelah film dokumenter divalidasi oleh lima orang validator, maka diperoleh hasil perhitungan nilai CVR dan CVI. Adapun hasil perhitungan CVR dan CVI dapat dilihat pada Tabel 1.

Tabel 1. Nilai CVR dan CVI Media Pembelajaran Film Dokumenter Kelas X SMA

\begin{tabular}{|c|c|c|c|c|c|c|c|c|c|}
\hline \multirow[t]{2}{*}{ Aspek } & \multirow[t]{2}{*}{ No } & \multirow[t]{2}{*}{ Kriteria } & \multicolumn{5}{|c|}{ Validator } & \multirow[t]{2}{*}{ CVR } & \multirow[t]{2}{*}{ Keterangan } \\
\hline & & & 1 & 2 & 3 & 4 & 5 & & \\
\hline \multirow[t]{4}{*}{ Format } & 1 & $\begin{array}{l}\text { Kesesuaian tampilan gambar dan } \\
\text { tulisan media video dengan konsep } \\
\text { pembelajaran }\end{array}$ & 4 & 4 & 4 & 4 & 4 & 1 & Valid \\
\hline & 2 & $\begin{array}{l}\text { Kesesuaian warna, tampilan gambar } \\
\text { dan tulisan }\end{array}$ & 3 & 3 & 3 & 3 & 4 & 1 & Valid \\
\hline & 3 & $\begin{array}{l}\text { Kejelasan antara suara background } \\
\text { dan narator }\end{array}$ & 3 & 4 & 3 & 4 & 4 & 1 & Valid \\
\hline & 4 & $\begin{array}{l}\text { Kejelasan suara narator dalam media } \\
\text { film dokumenter }\end{array}$ & 4 & 4 & 4 & 4 & 4 & 1 & Valid \\
\hline \multirow[t]{5}{*}{ Isi } & 5 & $\begin{array}{l}\text { Kesesuaian konsep dengan indikator } \\
\text { pada silabus }\end{array}$ & 4 & 4 & 4 & 4 & 4 & 1 & Valid \\
\hline & 6 & $\begin{array}{l}\text { Kesesuaian materi dengan tujuan } \\
\text { pembelajaran }\end{array}$ & 4 & 4 & 4 & 4 & 4 & 1 & Valid \\
\hline & 7 & $\begin{array}{l}\text { Media film dokumenter dapat } \\
\text { membantu guru dalam menjelaskan } \\
\text { submateri konsep keanekaragaman } \\
\text { gen, jenis, ekosistem }\end{array}$ & 4 & 4 & 4 & 4 & 3 & 1 & Valid \\
\hline & 8 & $\begin{array}{l}\text { Media film dokumenter dibuat } \\
\text { dengan kreatif untuk } \\
\text { mepresentasikan realistis mengenai } \\
\text { submateri keanekaragaman gen, } \\
\text { jenis, dan ekosistem }\end{array}$ & 4 & 4 & 4 & 4 & 4 & 1 & Valid \\
\hline & 9 & $\begin{array}{l}\text { Media film dokumenter dapat } \\
\text { memberikan pesan pembelajaran }\end{array}$ & 4 & 4 & 4 & 3 & 4 & 1 & Valid \\
\hline
\end{tabular}


Jurnal Mangifera Edu, Volume 5, Nomor 1, Juli 2020, 26-37

\begin{tabular}{|c|c|c|c|c|c|c|c|c|c|}
\hline \multirow[t]{4}{*}{ Aspek } & \multirow[t]{3}{*}{ No } & \multirow[t]{2}{*}{ Kriteria } & \multicolumn{5}{|c|}{ Validator } & \multirow[t]{2}{*}{ CVR } & \multirow[t]{2}{*}{ Keterangan } \\
\hline & & & 1 & 2 & 3 & 4 & 5 & & \\
\hline & & $\begin{array}{l}\text { secara ringkas dan jelas mengenai } \\
\text { materi yang disampaikan }\end{array}$ & & & & & & & \\
\hline & 10 & $\begin{array}{l}\text { Kelengkapan informasi yang } \\
\text { disajikan media film dokumenter }\end{array}$ & 4 & 3 & 3 & 4 & 4 & 1 & Valid \\
\hline Bahasa & 11 & $\begin{array}{l}\text { Bahasa yang digunakan mudah } \\
\text { dipahami }\end{array}$ & 4 & 4 & 4 & 4 & 4 & 1 & Valid \\
\hline \multirow[t]{3}{*}{ Efektif } & 12 & $\begin{array}{l}\text { Media film dokumenter berkualitas } \\
\text { sehingga dapat digunakan dalam } \\
\text { jangka waktu lama }\end{array}$ & 4 & 4 & 4 & 4 & 4 & 1 & Valid \\
\hline & 13 & $\begin{array}{l}\text { Media film dokumenter dapat } \\
\text { mengefektifkan waktu belajar } \\
\text { peserta didik }\end{array}$ & 4 & 4 & 4 & 4 & 3 & 1 & Valid \\
\hline & 14 & $\begin{array}{l}\text { Media film dokumenter mudah } \\
\text { digunakan belajar perorangan } \\
\text { maupun kelompok }\end{array}$ & 4 & 4 & 4 & 4 & 4 & 1 & Valid \\
\hline CVI & & & & & & & & 1 & Valid \\
\hline
\end{tabular}

Keterangan: CVR = Content Validity Ratio (Rasio Validitas Konten)

$\mathrm{CVI}=$ Content Validity Index (Indeks Validitas Konten)

Layak tidaknya film dokumenter ini dijadikan media pembelajaran, maka media haruslah divalidasi terlebih dahulu menggunakan lembar validasi oleh ahli. Adapun hasil validasi dari lima orang validator ahli tersebut dapat dilihat pada Tabel 1. Semua kriteria tersebut dinyatakan valid. Hal ini karena nilai minimum untuk CVR adalah 1 sehingga apabila rerata nilai dari masing-masing kriteria memenuhi nilai minimum tersebut, media tersebut tersebut dinyatakan Valid.

Pada aspek format terdiri atas empat kriteria yaitu pada kriteria yang pertama kesesuaian tampilan gambar dan tulisan pada film dokumenter dengan konsep pembelajaran, mendapatkan nilai CVR sebesar 1 dengan kelima validator memberikan nilai 4 . Nilai tersebut diperoleh karena film dokumenter memiliki ukuran gambar dan tulisan yang proposional, mudah untuk dipahami, dan menggunakan pendekatan saintifik. Kriteria yang kedua yaitu kesesuaian warna, tampilan gambar, dan tulisan. Pada kriteria ini empat validator memberikan nilai 3 dan satu validator memberikan nilai 4 sehingga nilai CVR pada kriteria ini adalah 1. Hal ini disebabkan pada kriteria ini, film dokumenter mengandung warna tulisan tersamarkan/tidak jelas karena ditutupi warna latar tetapi tulisan masih dapat dibaca. Pada kriteria ketiga yaitu kejelasan antara suara background dan narator, dua validator memberikan nilai 3 dan tiga validator memberikan nilai 4 sehingga didapatkan nilai CVR sebesar 1. Nilai 3 yang diberikan oleh validator artinya menurut 2 validator, suara musik background tidak jelas tetapi suara narator jelas. Pada kriteria keempat, yaitu 
kejelasan suara narator dalam media film dokumenter. Pada kriteria ini, kelima validator memberikan nilai 4 sehingga nilai CVR yang didapatkan sebesar 1. Hal ini mengindikasikan bahwa narator dalam film dokumenter mudah dipahami, serta menggunakan bahasa yang baik, benar dan efektif. Pada aspek format ini validator menilai bahwa materi yang ditampilkan dalam film dokumenter singkat, padat, dan jelas dengan tampilan gambar dan tulisan yang sesuai materi sehingga tidak berlebihan. Selain itu materi yang disajikan sesuai dengan konsep pembelajaran deyaitu membahas konsep keanekaragaman gen, jenis dan ekosistem yaitu pendekatan saintifik. Oleh sebab itu aspek ini memenuhi nilai minimum untuk dinyatakan valid. Hal ini sesuai dengan pendapat Faramita et al. (2018), bahwa film dokumenter sebagai media pembelajaran harus mengemas teks, gambar, dan suara yang sesuai dengan materi.

Pada aspek isi terdiri dari enam kriteria yaitu, kriteria yang kelima adalah kesesuaian konsep dengan indikator pada silabus. Pada kriteria ini, kelima validator memberikan nilai 4 sehingga nilai CVR dari kriteria ini adalah 1 sehingga termasuk kedalam kategori valid. Pada kriteria ini, film dokumenter menerapkan pendekatan saintifik yang bertujuan agar peserta didik dapat menjelaskan perbedaan berbagai tingkat keanekaragaman hayati dan membuat hasil observasi atau pengamatan berbagai tingkat keanekaragaman hayati di Indonesia. Namun, alur penyampaian materi tetap mengikuti kurikulum yaitu mulai dari penyampaian konsep keanekaragaman gen, dilanjutkan dengan keanekaragaman jenis, dan keanekaragaman ekosistem. Pada kriteria keenam, kesesuaian materi dengan tujuan pembelajaran, kelima validator memberikan nilai 4 sehingga nilai CVR dari kriteria ini adalah 1 yang berarti termasuk kedalam kategori valid. Pada kriteria ini, validator menyimpulkan bahwa film dokumenter memuat materi ringkas, tidak menimbulkan multi penafsiran dan sesuai dengan tujuan pembelajaran.

Pada kriteria ketujuh, yaitu media film dokumenter dapat membantu guru dalam menjelaskan submateri konsep keanekaragaman gen, jenis, dan ekosistem, empat validator memberikan nilai 4 dan satu validator memberikan nilai 3. Nilai CVR pada kriteria ini adalah 1 sehingga termasuk kedalam kategori valid. Pada kriteria ini validator menganggap media film dokumenter dapat mengatasi keterbatasan ruang dan waktu dalam penyajian konsep dan contoh-contohnya, menampilkan penjelasan audio visual mengenai submateri keanekaragaman gen, jenis dan ekosistem, dan teknis penyajian materi menggunakan teknologi terkini sehingga dapat dilakukan penghentian atau pengulangan sesuai kemauan. Ernanida \& Al Yusra (2019) menyatakan bahwa salah satu karakteristik film dalam proses pembelajaran adalah mengatasi keterbatasan jarak dan waktu sehingga dapat membuat 
pembelajaran menjadi efektif dan efisien. Film dokumenter juga dapat menggambarkan suatu proses secara tepat yang dapat disaksikan secara berulang-ulang (Novita et al., 2019). Pada kriteria kedelapan, yaitu media film dokumenter dibuat dengan kreatif untuk mepresentasikan realistis mengenai submateri keanekaragaman gen, jenis, dan ekosistem, mendapatkan nilai 4 dari kelima validator sehingga CVR pada kriteria ini adalah 1 sehingga termasuk kedalam kategori valid. Pada kriteria ini, validator menyimpulkan bahwa film dokumenter seluruhnya merupakan rekaman nyata dari hasil inventarisasi Nepenthes, ada tampilan gerak sehingga terlihat hidup dan menggunakan teknik gerak lambat atau cepat. Film bergerak dengan cepat dan bergantian sehingga memberikan visual yang kontinu sehingga dapat menggambarkan suatu objek yang bergerak bersama-sama dengan suara alamiah atau suara yang sesuai (Bradbury \& Guadagno, 2020) sehingga dapat menggunakan teknik-teknik terutama gerak lambat ataupun cepat (Winston, 2019).

Media film dokumenter dapat memberikan pesan pembelajaran secara ringkas dan jelas mengenai materi yang disampaikan merupakan kriteria kesembilan pada aspek isi yang mendapatkan nilai 4 dari empat validator dan 3 dari satu validator. Pada kriteria ini nilai CVR yang didapatkan adalah 1. Pada kriteria ini, validator menyimpulkan bahwa gambar dan kalimat dalam film dokumenter menginformasikan dengan jelas, tidak saling menutupi dan bebas bias (pesan yang meragukan). Satu validator memberikan nilai 3 pada kriteria ini karena pada kurangnya angka dan nilai penting ditampilkan pada film untuk memperjelas informasi yang disampaikan. Pada kriteria ini, validator memberikan saran untuk menambahkan angka atau kalimat penting untuk memperjelas penyampaian informasi. Kriteria kesepuluh untuk aspek ini adalah kelengkapan informasi yang disajikan media film dokumenter. Pada kriteria ini nilai yang diberikan oleh tiga dari lima validator adalah 4 dan dua validator memberikan nilai 3. Berdasarkan penilaian tersebut, nilai CVR yang didapatkan adalah sebesar 1 dan termasuk kedalam kategori valid. Agar mendapatkan nilai 4 dari validator, film harus memuat materi berisi gambar, warna yang menarik, penjelasan mengenai masing-masing jenis Nepenthes yang jelas dan ajakan untuk menjaga keanekaragaman hayati. Nilai 3 yang didapatkan dari validator mengindikasikan bahwa penjelasan masing-masing Nepenthes kurang jelas/tidak lengkap. Hal ini terlihat dari saran yang didapatkan yaitu yang perlu ditambahkan penjelasan mengenai tanah organosol yang merupakan jenis tanah yang dapat ditumbuhi oleh Nepenthes (Mansur, 2006) dan perlunya dimasukkan data mengenai kebakaran hutan yang terjadi sepanjang 2018.

Pada aspek bahasa hanya terdapat satu kriteria yaitu penggunaan bahasa yang mudah dipahami. Pada kriteria ke-11 ini kelima validator memberikan nilai 4 sehingga CVR dari 
kriteria ini adalah 1 dan termasuk kedalam kategori valid. Berdasarkan hasil validasi, validator beranggapan bahwa film dokumenter menggunakan bahasa yang lugas dan menggunakan bahasa formal sehari-hari sehingga mudah dimengerti. Hal ini sesuai dengan pendapat Asyhar (2012), bahwa media yang baik harus memperlihatkan kejelasan sajian terutama penggunaan bahasa. Penggunaan bahasa yang baik, singkat, padat dan jelas dapat mempermudah peserta didik memahami maksud yang terkandung pada sebuah media.

Pada aspek efektif terdiri dari tiga kriteria yaitu pada kriteria yang ke-12 adalah media film dokumenter berkualitas sehingga dapat digunakan dalam jangka waktu lama dengan kelima validator memberikan nilai 4 untuk kriteria ini sehingga didapatkan nilai CVR sebesar 1 dan termasuk kedalam kategori valid. Nilai 4 yang diberikan oleh validator mengindikasikan bahwa film dokumenter ini menggunakan teknologi baru, berisi informasi terbaru, dan tidak berisi komponen yang usang. Hal ini sejalan dengan pernyataan Titin (2016), bahwa salah satu karakteristik dari film ialah dapat menggambarkan peristiwaperistiwa masa lalu secara realistis dalam waktu yang singkat. Pada kriteria yang ke-13 yaitu media film dokumenter dapat mengefektifkan waktu belajar peserta didik. Pada kriteria ini, kelima validator memberikan nilai 4 sehingga nilai CVR dari kriteria ini adalah 1 dan termasuk kedalam kategori valid. Validator menyimpulkan bahwa materi yang disajikan sangat baik sehingga mudah dipahami dan mempermudah proses informasi. Pada kriteria yang ke-14 yaitu media film dokumenter mudah digunakan belajar perorangan maupun kelompok mendapatkan nilai 4 dari kelima validator dengan nilai CVR sebesar 1 sehingga termasuk kedalam kategori valid. Media film dokumenter konsep keanekaragaman gen, jenis dan ekosistem menggunakan format MP4 dan diupload ke youtube sehingga dapat di putar di berbagai platform digital.

Setelah dilakukan perhitungan seluruh CVR, selanjutnya dilakukan perhitungan CVI yang berfungsi sebagai kesimpulan dari seluruh hasil tes validasi (Lawshe, 1975). Berdasarkan hasil perhitungan CVI, nilai CVI yang didapatkan adalah 1 sehingga termasuk kedalam kategori valid. Setelah melakukan validasi, semua kekurangan media film dokumenter dari hasil validasi kemudian direvisi atau diperbaiki. Menurut Noviama (2013), revisi dari hasil validasi suatu media dilakukan dengan tujuan agar media layak digunakan dalam pembelajaran. 
Jurnal Mangifera Edu, Volume 5, Nomor 1, Juli 2020, 26-37

\section{SIMPULAN}

Berdasarkan hasil validasi film dokumenter berbasis Nepenthes sebagai media pembelajaran dinyatakan valid dengan nilai CVI sebesar 1 . Oleh sebab itu film dokumenter layak digunakan sebagai media pembelajaran submateri keanekaragaman gen, jenis, dan ekositem di kelas X SMA.

\section{DAFTAR PUSTAKA}

Afifah, W. N., \& Marlina, R. (2016). Kelayakan Media Film Dokumenter Inventarisasi Tumbuhan Obat di Desa Bange pada Kelas X SMA. Jurnal Pendidikan Dan Pembelajaran Khatulistiwa, 5(1).

Asyhar, R. (2012). Kreatif Mengembangkan Media Pembelajaran. Jakarta: Referensi Jakarta.

Bradbury, J. D., \& Guadagno, R. E. (2020). Documentary Narrative Visualization: Features and Modes of Documentary Film in Narrative Visualization. Information Visualization, 19(4), 339-352.

Chulsum, U., \& Novia, W. (2016). Kamus Besar Bahasa Indonesia. Surabaya: Yoshiko Press.

Cikka, H. (2019). Sinopsis dalam Pembelajaran Sejarah (Cara Mudah Memahami dan Mengingat Peristiwa Sejarah). Scolae: Journal of Pedagogy, 2(2), 300-306.

Clarke, C., \& Moran, J. A. (2016). Climate, Soils and Vicariance-Their Roles in Shaping the Diversity and Distribution of Nepenthes in Southeast Asia. Plant and Soil, 403(1), 3751.

Dara, E. N., \& Panjaitan, R. G. P. (2016). Pengaruh Film Dokumenter terhadap Hasil Belajar Siswa pada Materi Ruang Lingkup Biologi. Jurnal Pendidikan Dan Pembelajaran Khatulistiwa, 5(3).

Ernanida, E., \& Al Yusra, R. (2019). Media Audio Visual dalam Pembelajaran PAI. Murabby: Jurnal Pendidikan Islam, 2(1), 101-112.

Faramita, G., Daningsih, E., \& Yokhebed, Y. (2018). Kelayakan Film Dokumenter Pembuatan Bingka Pepaya Submateri Peran Tumbuhan di Bidang Ekonomi. Edukasi: Jurnal Pendidikan, 16(2), 267-280.

Handayani, T. R. I. (2017). Flower Morphology, Floral Development and Insect Visitors to Flowers of Nepenthes mirabilis. Biodiversitas Journal of Biological Diversity, 18(4), $1624-1631$.

Joshi, A., Kale, S., Chandel, S., \& Pal, D. K. (2015). Likert scale: Explored and Explained. Current Journal of Applied Science and Technology, 396-403.

Khulsum, U., Hudiyono, Y., \& Sulistyowati, E. D. (2018). Pengembangan Bahan Ajar 
Jurnal Mangifera Edu, Volume 5, Nomor 1, Juli 2020, 26-37

Menulis Cerpen dengan Media Storyboard pada Siswa Kelas X SMA. Diglosia: Jurnal Kajian Bahasa, Sastra, Dan Pengajarannya, 1(1), 1-12.

Kurniawan, G. E. (2018). Pengembangan Modul Pembelajaran Berbasis Model Problem Solving Untuk Meningkatkan High Order Thinking Skill pada Pelajaran IPA Pokok Bahasan Fluida Pelajaran IPAPokok Bahasan Fluida Statis Siswa Kelas VIII SMPN 7 Cirebon. Jurnal Mangifera Edu, 3(1), 62-71.

Lawshe, C. H. (1975). A Quantitative Approach to Content Validity. Personnel Psychology, 28(4), 563-575.

Mansur, M. (2006). Nepenthes: Kantong Semar yang Unik. Penebar Swadaya.

Maxtuti, I. O. (2013). Pengembangan Komik Keanekaragaman Hayati sebagai Media Pembelajaran Bagi Siswa SMA Kelas X. BioEdu, 2(2), 128-133.

Munadi, Y. (2013). Media Pembelajaran. GP press group.

Noviama, R. R. (2013). Pengembangan Media Digital Games Based Learning (DGBL) pada Pembelajaran Sistem Reproduksi Manusia di SMP. Unnes Journal of Biology Education, 1, 58-65.

Novita, L., Sukmanasa, E., \& Pratama, M. Y. (2019). Penggunaan Media Pembelajaran Video terhadap Hasil Belajar Siswa SD. Indonesian Journal of Primary Education, $3(2), 64-72$.

Pamuji, W. H. (2020). Penulisan Skenario dalam Pembuatan Film Pendek Bergenre Drama dengan Tema Gangguan Kesehatan Mental Yang Berupa "Self-Harm.” Universitas Dinamika.

Panjaitan, R. G. P., Wahyuni, E. S., \& Mega, M. (2019). Film Dokumenter Sebagai Media Pembelajaran Submateri Zat Aditif. JPBIO (Jurnal Pendidikan Biologi), 4(2), 52-59.

Pratiwi, E. I., Yeni, L. F., \& Wahyuni, E. S. (2015). Pembuatan Video Teknik Isolasi dan Karakterisasi Bakteri Asam Laktat Pekasam Ikan Kembung Kelas X. Jurnal Pendidikan Dan Pembelajaran Khatulistiwa, 4(5).

Rahman, D. F. (2017). Pengembangan Perangkat Pembelajaran Ekosistem di SMA dengan Penugasan Presentasi Poster. Jurnal Mangifera Edu, 2(1), 8-19.

Rikarno, R. (2015). Film Dokumenter sebagai Sumber Belajar Siswa. Ekspresi Seni: Jurnal Ilmu Pengetahuan Dan Karya Seni, 17(1), 129-149.

Rusman, M. P. (2017). Belajar \& Pembelajaran: Berorientasi Standar Proses Pendidikan. Prenada Media.

Sadiman, A. S., Rahardjo, R., Haryono, A., \& Rahardjito, C. A. S. (2000). Media Pendidikan: Pengertian dan Pemanfaatannya. Jakarta: PT. Raja Grafindo.

Smaldino, S. E., Lowther, D. L., \& Russell, J. D. (2014). Instructional Technology \& Media 
Jurnal Mangifera Edu, Volume 5, Nomor 1, Juli 2020, 26-37

for Learning: Teknologi Pembelajaran dan Media untuk Belajar. Prenada Media.

Sudjana. (2009). Teknologi Pengajaran. Sinar Baru Algensindo.

Sugiyono, S. (2010). Metode penelitian kuantitatif dan kualitatif dan $R \& D$. Alfabeta Bandung.

Titin, T. (2016). Penyusunan Perangkat Pembelajaran pada Materi Ruang Lingkup Biologi Kelas X SMA. Jurnal Pendidikan Matematika Dan IPA, 7(1), 45-56.

Utami, C. D. (2010). Film Dokumenter Sebagai Media Pelestari Tradisi. Acintya Jurnal Penelitian Seni Budaya, 2(1).

Wardhani, R. K., \& Sudjudi, I. (2014). Perancangan Video Dokumenter “Autisme.” Visual Communication Design, 3(1), 180546.

Winston, B. (2019). The Documentary Film Book. Bloomsbury Publishing. 